\title{
Review \\ Therapeutic Potential of AAV1-Rheb(S16H) Transduction against Neurodegenerative Diseases
}

\author{
Youngpyo Nam ${ }^{1,+}$, Gyeong Joon Moon ${ }^{2,3,+}$ and Sang Ryong Kim ${ }^{1,4,5, * \mathbb{C}}$ \\ 1 Brain Science and Engineering Institute, Kyungpook National University, Daegu 41944, Korea; \\ blackpyo2@naver.com \\ 2 Center for Cell Therapy, Asan Institute for Life Science, Asan Medical Center, Seoul 05505, Korea; \\ gj.moon@amc.seoul.kr \\ 3 Department of Convergence Medicine, University of Ulsan College of Medicine, Seoul 05505, Korea \\ 4 School of Life Sciences, Kyungpook National University, Daegu 41566, Korea \\ 5 BK21 FOUR KNU Creative BioResearch Group, Kyungpook National University, Daegu 41566, Korea \\ * Correspondence: srk75@knu.ac.kr; Tel.: +82-53-950-7362; Fax: +82-53-943-2762 \\ + These authors contributed equally to this work.
}

Citation: Nam, Y.; Moon, G.J.; Kim, S.R. Therapeutic Potential of AAV1-Rheb(S16H) Transduction against Neurodegenerative Diseases. Int. J. Mol. Sci. 2021, 22, 3064. https://doi.org/10.3390/ijms22063064

Academic Editor: Rosalba Parenti

Received: 25 January 2021

Accepted: 16 March 2021

Published: 17 March 2021

Publisher's Note: MDPI stays neutral with regard to jurisdictional claims in published maps and institutional affiliations.

Copyright: (c) 2021 by the authors. Licensee MDPI, Basel, Switzerland. This article is an open access article distributed under the terms and conditions of the Creative Commons Attribution (CC BY) license (https:/ / creativecommons.org/licenses/by/ $4.0 /)$.

\begin{abstract}
Neurotrophic factors (NTFs) are essential for cell growth, survival, synaptic plasticity, and maintenance of specific neuronal population in the central nervous system. Multiple studies have demonstrated that alterations in the levels and activities of NTFs are related to the pathology and symptoms of neurodegenerative disorders, such as Parkinson's disease (PD), Alzheimer's disease (AD), and Huntington's disease. Hence, the key molecule that can regulate the expression of NTFs is an important target for gene therapy coupling adeno-associated virus vector (AAV) gene. We have previously reported that the Ras homolog protein enriched in brain (Rheb)-mammalian target of rapamycin complex 1 (mTORC1) axis plays a vital role in preventing neuronal death in the brain of AD and PD patients. AAV transduction using a constitutively active form of Rheb exerts a neuroprotective effect through the upregulation of NTFs, thereby promoting the neurotrophic interaction between astrocytes and neurons in AD conditions. These findings suggest the role of Rheb as an important regulator of the regulatory system of NTFs to treat neurodegenerative diseases. In this review, we present an overview of the role of Rheb in neurodegenerative diseases and summarize the therapeutic potential of AAV serotype 1 (AAV1)-Rheb(S16H) transduction in the treatment of neurodegenerative disorders, focusing on diseases, such as AD and PD.
\end{abstract}

Keywords: neurotrophic factor; Rheb(S16H); neurodegenerative disease; Alzheimer's disease; Parkinson's disease

\section{Introduction}

Neurodegenerative diseases are debilitating disorders characterized by the gradual loss of anatomically or physiologically related function or structure of the central nervous system and include various diseases with different pathological patterns and clinical manifestations, such as Alzheimer's disease (AD), Huntington's disease (HD), Parkinson's disease (PD), and amyotrophic lateral sclerosis (ALS) [1-3]. These diseases are pathophysiologically diverse, causing cognitive and memory impairments or affecting a person's ability to move, breathe, and speak [4-7]. Although several studies have focused on the treatment of neurodegenerative diseases, a relevant treatment is yet to be developed. An in-depth understanding of the causes and mechanisms of each disease is essential for effective treatment of neurodegenerative diseases. These diseases are characterized by the selective loss of vulnerable populations of specific neurons due to various factors, such as increased number of reactive oxygen species [8], excitotoxicity [9], synaptic dysfunction [10], inflammation [11], impaired protein degradation systems [12], endoplasmic reticulum stress [13], and mitochondrial dysfunction [14]. Although the precise mechanism 
responsible for neuronal loss and functional disruption in these diseases still remains unknown, several studies have attempted treatment strategies through the protection of damaged neuronal cells. Several studies have also demonstrated that a decrease in the levels of neurotrophic factors (NTFs), such as brain-derived neurotrophic factor (BDNF) and ciliary neurotrophic factor (CNTF), is associated with the pathology of neurodegenerative diseases [15-20] and that this decrease is closely linked to neuronal cell death [21,22]. These findings suggest that sustained expression of NTFs is effective in protecting neurons in neurodegenerative diseases, such as $\mathrm{AD}$ and $\mathrm{PD}$, and thus, the discovery and regulation of key molecules capable of regulating the production of NTFs is a potential therapeutic strategy for neurodegenerative diseases.

Ras homolog protein enriched in brain (Rheb) is a member of the Ras superfamily, which consists of Rheb1 and Rheb2 [23]. Rheb1 and Rheb2 proteins show a 51\% similarity in their amino acid composition [24]. These proteins are expressed in high concentrations in various regions of the brain, including the hippocampus, cerebral cortex, frontal lobe, temporal lobe, and occipital pole $[25,26]$. The expression levels of Rheb are increased as an immediate early response to toxic stimulation, such as seizure and high-frequencyinduced synaptic stimuli in an N-methyl-d-aspartate (NMDA)-dependent manner [26,27]. Further, Rheb can be activated by growth factors, such as nerve growth factor (NGF), epithelial growth factor, and fibroblast growth factor, in cultured neuronal cells [26], and it is associated with neuronal differentiation, growth, axonal regeneration, autophagy, energy homeostasis, amino acid uptake, and aging [24,28-30]. Previous studies have demonstrated that inhibition of the mammalian target of rapamycin (mTOR) accelerates autophagy, leading to the reduction of the levels of neurotoxic aggregate proteins such as Tau, $\alpha$-synuclein, and ataxin [31-33], which are associated with diseases such as AD, PD, and spinal ataxia [34-36]. However, a recent study showed that Rheb activity was reduced in striatal tissues of patients with $\mathrm{HD}$ and mice with $\mathrm{HD}$, and that activation of mammalian target of rapamycin complex 1 (mTORC1) by introducing caRheb, a constitutively active form, could mitigate the metabolic and degenerative phenotypes in striatal tissues of mice with HD [37]. Furthermore, there is accumulated evidence indicating the neuroprotective effects through increased Rheb expression for neurodegenerative diseases, including spinal cord injury, $\mathrm{AD}$, and $\mathrm{PD}$. It has been reported that the expression of adeno-associated virus vector $(\mathrm{AAV})$-caRheb in spinal neurons activates proteins downstream of mTOR and enhances intrinsic growth potential to cause axonal regeneration after spinal cord injury [28]. Another study showed that overexpression of Rheb depletes the levels of $\beta$-site amyloid precursor protein-cleaving enzyme 1 protein through proteasomal and lysosomal pathways, leading to reduction of $A \beta$ generation [38]. Recently, it has been reported that activation of Rheb can protect neurons against neurotoxic conditions in the adult brain through neurotrophic interactions (such as BDNF, GDNF, and CNTF production) between neurons and astrocytes [39-42].

These findings suggest that Rheb involvement in neurodegenerative diseases and its important role in the production of various NTFs can be considered as one of the potential therapeutic targets for neurodegenerative diseases. This review provides insights into the involvement of the Rheb/mTORC1 signaling pathway in neurodegenerative diseases and the neuroprotective effects of Rheb as a potential therapeutic target, focusing on $\mathrm{AD}$ and PD.

\section{Importance of Supporting Neurotrophic Factors as a Therapeutic Strategy for Neurodegenerative Diseases}

Despite the several in-depth studies that have been conducted over previous decades on neurodegenerative diseases, these disorders remain poorly understood. Most neurodegenerative diseases, such as AD [43-47], PD [48-52], and HD [53-57] are accompanied by the loss of specific cell populations (Table 1), leading to functional and structural dysfunctions. Studies conducted in recent years have reported that the reduction of NTF levels and the specific requirements for neurotrophic support are among the factors that have been implicated in neuronal degeneration in these diseases. NTFs support cell survival, 
growth, differentiation, and synaptic plasticity of developing and mature neurons [58,59]. Many previous studies have demonstrated that expression-level changes in specific NTFs, such as BDNF, CNTF, and glial cell line-derived neurotrophic factor (GDNF), are associated with the pathogenesis of neurodegenerative diseases, such as AD [19,60,61], PD [62-64], HD $[65,66]$, and ALS [67,68] (Table 2).

Table 1. Vulnerable neuronal populations in various neurodegenerative diseases.

\begin{tabular}{|c|c|c|c|}
\hline Neurodegenerative Diseases & Target System & Target Tissues & References \\
\hline \multirow{5}{*}{ Alzheimer's Disease } & Cholinergic Neurons & Nucleus basalis (NB) & [43] \\
\hline & Noradrenergic Neurons & Locus coeruleus (LC) & [44] \\
\hline & Dopaminergic Neurons & Substantia nigra (SN) & [45] \\
\hline & Serotonergic Neurons & Dorsal raphe nucleus (DRN) & [46] \\
\hline & Adrenergic Neurons & Rostral ventral lateral medulla C-1 neurons & [47] \\
\hline \multirow{5}{*}{ Parkinson's Disease } & Cholinergic Neurons & Nucleus basalis (NB) & [50] \\
\hline & Noradrenergic Neurons & Locus coeruleus (LC) & [52] \\
\hline & Dopaminergic Neurons & Substantia nigra (SN) & {$[49]$} \\
\hline & Serotonergic Neurons & Dorsal raphe nucleus (DRN) & [48] \\
\hline & Adrenergic Neurons & Rostral ventral lateral medulla C-1 neurons & [51] \\
\hline \multirow{4}{*}{ Huntington's Chorea } & Dopaminergic Neurons & Striatum & [56] \\
\hline & Cholinergic Neurons & Thalamostriatal axodendritic terminals & [53] \\
\hline & GABAergic Neurons & striatum & {$[54,55]$} \\
\hline & Glutamate Neurons & Striatum & [57] \\
\hline
\end{tabular}

Table 2. Animal model used to study the therapeutic effect of neurotrophic factors in various neurodegenerative diseases.

\begin{tabular}{|c|c|c|c|c|}
\hline Diseases & Animal Model & Neurotrophic Factor & Effect & Reference \\
\hline \multirow{6}{*}{ Alzheimer's Disease } & J20 (human APP mutant) & BDNF & Improve & [21] \\
\hline & $\operatorname{Tg} 2576$ & CNTF & Improve & [22] \\
\hline & Thrombin & $\begin{array}{l}\text { BDNF } \\
\text { CNTF }\end{array}$ & Improve & {$[39,40]$} \\
\hline & 5XFAD & $\begin{array}{l}\text { BDNF } \\
\text { CNTF }\end{array}$ & Improve & {$[42]$} \\
\hline & P301L & BDNF & Improve & {$[60]$} \\
\hline & Thrombin & GDNF & Improve & [69] \\
\hline \multirow{6}{*}{ Parkinson's Disease } & Inflammation (pKr-2) & $\begin{array}{l}\text { GDNF } \\
\text { BDNF }\end{array}$ & Improve & [41] \\
\hline & $\operatorname{Gdnf}(+/-)$ & GDNF & Improve & [63] \\
\hline & 6-OHDA & GDNF & Improve & [70] \\
\hline & $\alpha$-synuclein & GDNF & Worsen & {$[71,72]$} \\
\hline & $\mathrm{MPP}^{+}$ & CNTF & Improve & [73] \\
\hline & $\mathrm{MPP}^{+}$ & $\begin{array}{l}\text { GDNF } \\
\text { BDNF }\end{array}$ & Improve & [74] \\
\hline Huntington's Disease & $\operatorname{bdnf}(+/-)$ & BDNF & Improve & [65] \\
\hline \multirow{2}{*}{ Amyotrophic lateral sclerosis } & \multirow{2}{*}{ SOD1(G93A) } & GDNF & Improve & [75-77] \\
\hline & & BDNF & Improve & [78] \\
\hline
\end{tabular}


$\mathrm{AD}$ is a progressive psychiatric and neurodegenerative disease of unknown etiology. The clinical features of $\mathrm{AD}$ are a progressive decline in cognitive and memory processes and often difficulties with language [79-81]. The neuropathology of AD reveals extracellular deposits of amyloid plaques and the presence of numerous neurofibrillary tangles [82,83]. Neuronal degeneration and cognitive decline in patients with AD correlate with pathological changes in cholinergic neurons in several different regions $[47,84,85]$. The links between cholinergic changes and changes in NTF levels in AD have been emphasized by numerous studies. Several reports have indicated that the mRNA and protein expression levels of BDNF and tropomyosin receptor kinase B (TrkB) are reduced in the hippocampus and neocortex of postmortem brains of patients with AD [17,19,86]. Moreover, a recent study demonstrated that BDNF deficiency activates the JAK2/STAT3 pathway and leads to impairment in cognitive skill and synaptic plasticity [87]. Furthermore, the authors of that study confirmed that BDNF-deprivation-elicited events, including decreased BDNF expression and upregulated JAK2/STAT3 activation, also occur in the human AD brain. This observation supports that sustained BDNF expression and neurotrophic pathways are important factors in the protection of damaged neurons and consequently the inhibition of cognitive and memory decline. Previous preclinical and clinical studies have reported that GDNF, and its receptor alpha1 (GFR $\alpha 1$ ), levels in the brain were diminished in patients with $\mathrm{AD}$ and in a 3XTg AD mouse model $[61,88,89]$. In addition, it was reported that rearranged during transfection (RET) tyrosine kinase, which acts as a co-receptor of GDNF alongside GFRa1, was decreased in hippocampal neurons in a chronic cerebral hypoperfusion model of dementia [90]; moreover, overexpression of RET in AD neurons was related to neuronal survival $[61,91]$. Another in vitro and in vivo study showed that CNTF played a vital role in cognitive function recovery by stabilizing the levels of the synaptic protein PSD95 and synaptophysin in the Tg2576 AD mouse model [22]. These data suggest that reduced NTF levels contribute to neuronal degeneration in $\mathrm{AD}$ and that the regulation of NTFs is a potential treatment strategy for AD.

$\mathrm{PD}$ is a neurodegenerative disorder characterized by resting tremors, loss of postural reflexes, muscle rigidity, and bradykinesia, accompanied by festinating gait, cognitive decline, and postural malformations [92,93]. PD is pathologically characterized by the progressive death of heterogeneous populations of neurons, including dopaminergic, cholinergic, noradrenergic, and serotonergic neurons [48-52,94,95]. However, dopaminergic degeneration is considered a major cause of motor dysfunction and is the main target of existing and actively developed therapeutics. The degeneration of neurons in $\mathrm{PD}$ is due to various factors, including mitochondrial dysfunction, oxidative stress, excitotoxicity, and immune response [92,96]; however, the reduction of NTF levels in the degenerative region of the brain of patients with PD is also recognized as an important factor $[97,98]$. In postmortem examinations of the brains of controls and patients with $\mathrm{PD}$, in situ hybridization study showed that BDNF mRNA is expressed by dopaminergic neurons in the substantia nigra pars compacta (SNpc) of healthy controls without known neurological disease, but the mRNA expression of SNpc BDNF was reduced in the brain of patients with PD. However, surviving dopaminergic neurons in the SNpc region of PD brain also expressed BDNF mRNA. This result indicates the importance of BDNF expression in the survival of SNpc neurons [64]. Other studies have measured the amount of BDNF expression in the blood of healthy controls and patients with PD and found a decreased amount in patients with PD, which correlated with motor impairment in these patients [99-101]. The therapeutic effect of GDNF is controversial because conflicting results have been reported regarding the protection and maintenance of neurons in PD. Absence of GDNF in parvalbumin-expressing interneurons using Cre recombinase-based mice modulated significant loss of catecholamine neurons in the nigrostriatal pathway and locus coeruleus [102]. In addition, inhibition of GDNF expression in GDNF-null mice showed progressive hypokinesia and selective reduction of tyrosine hydroxylase mRNA levels, accompanied by distinct catecholaminergic apoptosis in the substantia nigra and ventral tegmental area [103]. These data clearly show that GDNF is indispensable for 
the survival of adult catecholaminergic neurons under physiological conditions. The expression of GDNF was reduced in the brain of an animal PD model, and the delivery of GDNF was shown to confer behavioral improvements in a 6-hydroxydopamine rat model of PD $[70,104]$. On the other hand, it is reported that GDNF is not required for the survival of catecholaminergic neurons under physiological conditions [105]. The lack of GDNF in embryonic and adult mice using loxP/Cre (Nestin-Cre, AAV5-Cre, and Esr1-Cre) systems showed no significant differences in the number of TH-positive neurons, motor function, or metabolite levels of dopamine. In addition, it has been reported that overproduction of GDNF in the $\alpha$-synuclein model does not prevent the aggregation of $\alpha$-synuclein in the $\mathrm{SN}$, loss of dopamine neurons by $\alpha$-synuclein, or motor dysfunction [71,72]. Importantly, a potential cause of the non-response of GDNF in PD has been reported. In this study, GDNF signaling was blocked in dopaminergic neurons overexpressing $\alpha$-synuclein in the rat SN. This block was accompanied by reduced expression of transcription factor Nurr1 and GDNF receptor Ret. Moreover, overexpression of Nurr1 restored the response to GDNF by $\alpha$-synuclein [106]. However, more recent studies have not demonstrated RET downregulation in PD animal models or postmortem sporadic PD patient brains [107]. Another study confirmed that GDNF prevented the accumulation of misfolded $\alpha$-synuclein in DA neuron cultures, and these effects were abolished by deletion of RET or inhibition of Src and Akt. Expression of constitutively active RET and GDNF-protected DA neurons from $\alpha$-synuclein preformed fibrils-induced $\alpha$-synuclein accumulation [108]. Trials investigating treatment of PD patients with GDNF have been in progress for 20 years. The initial research administered GDNF into the lateral ventricle of PD patients by the intracerebroventricular route [109]. In a multicenter, randomized, double-blind, placebocontrolled, sequential cohort study, 50 patients received GDNF monthly for 8 months and extended exposure up to an additional 20 months. However, no therapeutic effect was confirmed even at high concentrations of GDNF, and only side effects such as nausea, weight loss, and asymptomatic hyponatremia were reported. The lack of clinical effects in this trial was due to the possibility that GDNF was not effectively delivered into the target tissues, such as the putamen and $\mathrm{SN}$, when administered intracerebroventricularly. This led to the consideration of other strategies for the administration of GDNF, and subsequent trials used intraparenchymal administration of GDNF. In an open-label study, five patients with PD were treated with intraputamenal infusion of GDNF [110]. Patients receiving GDNF showed a 30-60\% improvement in the off-medication motor sub-score of the Unified Parkinson's Disease Rating Scale (UPDRS) and a 61\% improvement in the activities of daily living sub-score. Moreover, the beneficial effect of GDNF administration was confirmed by increased putamenal $18^{\mathrm{F}}$-dopa uptake measured by positron emission tomography (PET). In addition, it was confirmed that TH-immunopositive nerve fibers were increased in the postmortem brain tissue study of a patient who had received unilateral infusion for 48 months [111]. In other open-label studies, unilateral intraputamenal infusions of GDNF were performed in 10 patients with $\mathrm{PD}$, and motor dysfunction was improved without any serious side effects for 6 and 12 months [112,113]. Intraputamenal infusion of GDNF has shown promise for GDNF as a factor for clinical improvement in PD patients, and based on these results, a new clinical trial was conducted. GDNF was continuously administered into the posterior dorsal putamen using a chronic infusion pump, and the patient was evaluated for six months [114]. After six months, there was no difference from the placebo group, and some patients had problems developing neutralizing antibodies to GDNF. The study was withdrawn because of such stability issues; however, one patient experienced clinical improvement several years following GDNF treatment [115]. In another study, GDNF was administered intraputamenally every month for six months using a convectionenhanced delivery system $[116,117]$. There was no significant improvement in UPDRS score in GDNF-administered patients, but an increase in dopamine neuron function was confirmed by PET imaging. As a new strategy for delivering GDNF into target tissue, a method using viral vectors is currently being considered. AAV2, which enables long-term expression of transgenes without inducing an inflammatory response, is currently the 
vector of choice for clinical trials in PD patients. Currently, AAV2-GDNF is administered to the putamen, and treatment studies are ongoing (NCT04167540 and NCT01621581).

Various NTFs have been investigated in animal models for the treatment of other neurodegenerative diseases. ALS, the most common form of motor neuron disease, is a fatal adult-onset neurodegenerative disease that results in progressive and preferential degeneration and death of both the upper motor neurons of the motor cortex and the alpha lower motor neurons of the brain stem and spinal cord [118,119]. Several studies have documented the changes and neuroprotective effects of NTFs in ALS using in vivo and in vitro models. Expression levels of BDNF showed a significant reduction in spinal cord tissue obtained from SOD1 (G93A) mice, a murine model of ALS [67], and in lumbar spinal cord tissue of rat neonates that were injected intrathecally with CSF of ALS [68]. BDNF prevents cell death of motor neurons in the axotomized facial nucleus of the neonatal rat $[120,121]$ and mediates antiapoptotic effects by the ERK and PI3K pathways [122]. Recently, studies have also confirmed that the modulation of TrkB via enhanced BDNF signaling increased neuronal survival in degenerating neurons in vitro [123] and improved motor dysfunction and motor neuron loss in ALS model mice [78]. GDNF has also been reported to have a protective effect on motor neurons in ALS. Disruption of the TNFR1GDNF axis in astrocytes accelerates motor neuron degeneration and disease progression of ALS [75]. GDNF delivery prevents motor neurons from degenerating and preserves the axons that innervate the muscle; moreover, it has been shown to inhibit muscle atrophy in a transgenic mice model with the G93A human SOD1 mutation of ALS [76]. Furthermore, four-limb injection of AAV-GDNF in ALS mice postpones disease onset, delays progression of motor dysfunction, and prolongs life span [77]. However, despite the observation of these neuroprotective effects, there is also evidence that shows that therapeutic intervention of BDNF is unable to promote survival or prevent neuronal death in vivo. Many studies have shown that BDNF negatively affects motor neuron survival, which makes motor neurons more susceptible to damage [124,125]. Moreover, BDNF is effective in enhancing excitotoxic damage by enhancing glutamatergic activity in neurons [126]. Several studies have reported that BDNF plays a key role in motor neuron susceptibility to excitotoxicity $[125,127,128]$. In addition, muscles and CSF of patients with ALS exhibit elevated levels of BDNF [129] and GDNF [130]. These results suggest that the negative effects of NTFs also need to be considered for NTF therapeutic strategies for ALS.

Some NTFs such as BDNF, CNTF, and GDNF are promising candidates for future treatment as they affect the glial activation status and have a beneficial effect on the outcomes of neurodegenerative diseases. Exogenous BDNF treatment has been found to prevent the apoptotic cell death of astrocytes and neurons induced by neurotoxin 3-nitropropionic acid in culture conditions. BDNF treatment also regulates glutamate transporter expression and inflammatory responses in astrocytes. This observation suggests that the BDNF-induced beneficial function of astrocytes has therapeutic potential against neurodegenerative diseases [131]. Another study demonstrated that neuron-derived BDNF contributes to the regulation of synaptic density in the brain [132,133]. Exogenous CNTF increases the activation of astrocytes in the contralateral gray matter of the spinal cord when administered in a posttreatment manner after spinal cord injury (SCI) [134]. GDNF mRNA expression was found to be upregulated only in the astrocytes of the lesioned striatum in a 6-OHDA model of PD $[135,136]$. Another research showed that exogenous GDNF injections increased the number of phagocytic microglia in the spinal cord after SCI [137].

Taken together, evidence suggests that the absence of neurotrophic support contributes significantly to neurodegeneration and that NTFs have emerged as a promising therapeutic strategy for neurodegenerative diseases [138]. However, they have a relatively weak effect in the human clinical settings in contrast to their strong effect in animal models. Clinical trial design for investigating neuroprotection in neurodegenerative diseases remains challenging; however, inadequate designs may have resulted in failure to demonstrate neuroprotection. Therefore, preclinical work and careful consideration for all aspects of 
clinical trial design are required. There are several caveats that may affect test results and lead to test failure. Patients with neurodegenerative diseases have a wide variety of clinical symptoms and stages. Most clinical studies on NTFs observed changes in the CSF, plasma, or postmortem tissues during the late stage, so it is difficult to apply such changes to the early stages of the target tissue. Several studies of post-hoc analyses of trials have shown that clinical trials in patients at a late stage of disease have mostly failed, and patients with shorter illness duration or less severe symptoms have significant clinical benefit. These results suggest that patient selection and stratification have important implications for achieving clinical therapeutic effects with NTFs. Furthermore, more complex factors may be at play that inhibit the effects of NTFs in humans compared with that in animals. Animal models do not meticulously mimic the neurodegenerative processes and rate of disease progression in humans. For example, in addition to body weight, organ size and metabolic differences may also be the basis for the design of a clinical trial. Most importantly, protein delivery to the human brain has inherent difficulties, and it is probable that the low success rate of this approach is largely due to the protein not reaching the target at a sufficient concentration as well as off-target effects $[139,140]$. In addition, pharmacokinetic studies have shown that NTFs, such as BDNF [141] and CNTF [142], have a short half-life. This short half-life is a factor that further reduces the effectiveness of NTFs. CNTF and BDNF have extremely short half-lives of less than $2.9 \mathrm{~min}$ and $10 \mathrm{~min}$, respectively, following intravenous injection into rodents. This short half-life is a factor that reduces the effectiveness of NTFs. The concentration of NTFs is also considered an important factor in clinical trials. Excessive upregulation of NTFs in the adult brain may contribute to epileptogenesis or induce an abnormal formation of synaptic networks $[129,143,144]$. These findings suggest that appropriate control of balance of NTFs is important for treating neurodegenerative diseases. Therefore, sustained expression of NTFs using an appropriate delivery system that protects the neurons in a specific target area is considered a viable therapeutic strategy for neurodegenerative disorders.

\section{Rheb-mTORC1 Signaling against Neurodegenerative Diseases}

Rheb is inactivated in the form of guanosine diphosphate-bound Rheb by a tuberous sclerosis complex (TSC) complex consisting of TSC1 (hamartin), TSC2 (tuberin), and TBC1D7 that act as guanosine triphosphatase (GTP)-activating proteins (GAT) [145]. Insulin and insulin-like growth factor 1 (IGF1), which activate G-protein-coupled and IGF1 receptors on target cell membranes, trigger the lipid kinase phosphatidylinositol-3 kinase (PI3K)-serine/threonine kinase Akt signaling pathway [146-148]. Activated Akt phosphorylates at the conserved consensus phosphorylation sequences of TSC2 and downregulates the GAP activity of the TCS complex [146]. Consequently, the activated form of GTP-bound Rheb increases and interacts with mTORC1 (Figure 1). It is well known that Rheb acts as a key activator of mTORC1, and its deletion can result in decreased cortical thickness and increased demyelination in the brain [37]. Accumulating evidence indicates that Rheb upregulation prevents neuronal loss and thus protects against neurodegenerative diseases, including AD [38,42], PD [73,149,150], and SCI [28].

Interestingly, in this context, our own recent studies have shown that a higher constitutive level of Rheb(S16H), a constitutively active mutant protein transduced using AAV serotype 1 (AAV1), can protect hippocampal neurons in the adult brain against neurotoxic conditions through neurotrophic interactions between neurons and astrocytes [39-41,151]. It is well known that mTORC1 acts as a downstream effector of Rheb. Rheb-mTORC1 signaling regulates various transcriptional and translational mechanisms associated with cell growth, proliferation, protein synthesis, and synaptic plasticity [152]. Previous studies have shown that the activation of Rheb upregulates the expression of NTFs such as BDNF, CNTF, and GDNF through the activation of mTORC1 in the adult brain. Moreover, several studies have demonstrated the role of the Rheb-mTOR axis in synaptic morphogenesis and axon elongation [153,154]. Akt-Rheb-mTORC1 signaling can enhance axon length and axon number per neuron as well as the number of neurons with multiple axons [155]. 
Furthermore, learning, memory, and long-term synaptic plasticity depend on de novo protein synthesis. The activation of the Rheb-mTOR axis acts as an important signaling pathway for the maintenance of long-term potentiation (LTP) and learning and memory functions [32,156]. It has been reported that Rheb interacts with beta-secretase 1 (BACE1) to inhibit BACE1 activity in the hippocampus of mouse brain, leading to the reduction of $A \beta$ generation [38]. In the brains of patients with $A D$, it was shown that the expression of Rheb was significantly downregulated compared to that a normal healthy brain [157]. Depletion of Rheb can lead to the behavioral hallmarks of AD progression, such as defects in spatial memory functions [158].

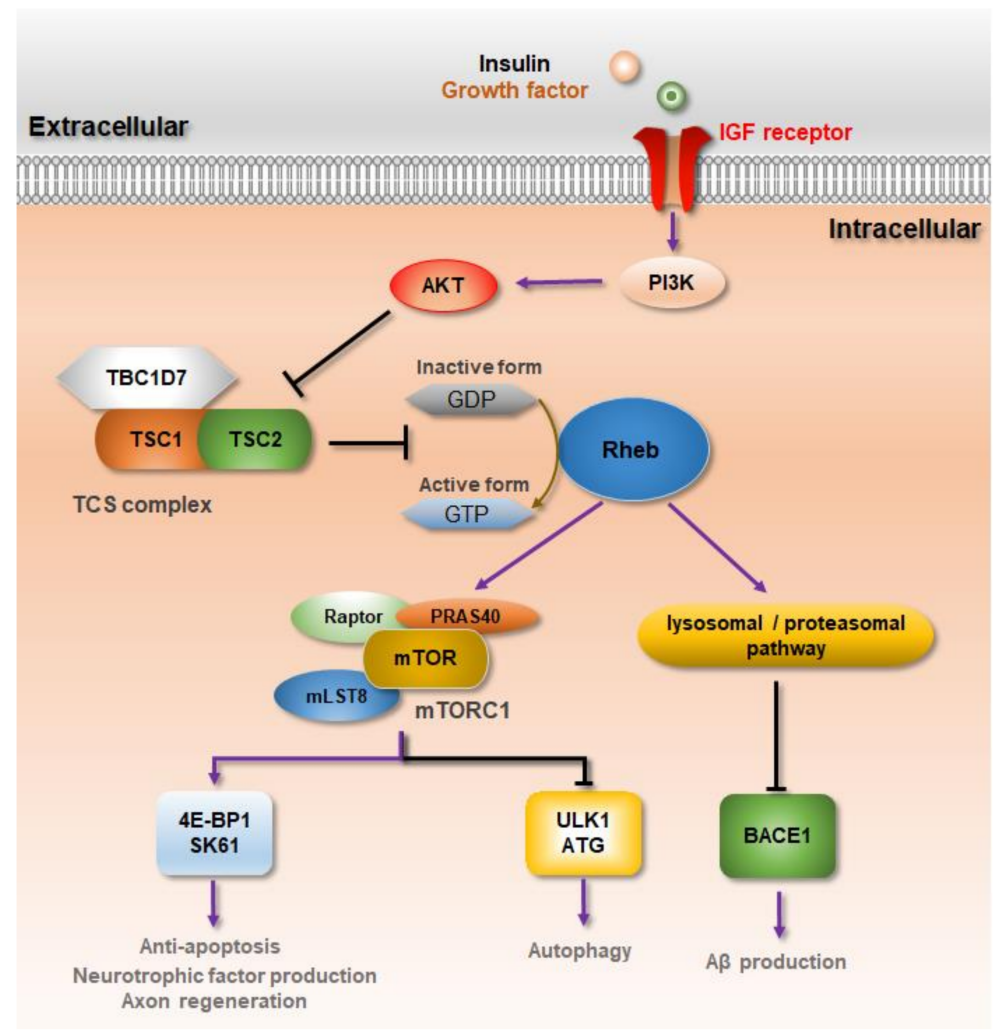

Figure 1. Rheb-mTORC1 signaling pathway in neurodegeneration. Binding of growth factors, such as insulin or insulin-like growth factor (IGF), to receptors stimulates PI3K signaling. The activity of PI3K-AKT mediates the activation of Rheb-mTORC1 by disinhibiting the Rheb-inhibiting TCS complex. Fully activated Rheb-mTORC1 phosphorylates S6K-1 or 4E-BP1 activate the protein of the translation machinery. In neurodegenerative diseases, Rheb-mTORC1 has negative effects, such as inhibition of autophagy, but promotes cell growth, regeneration, and neuroprotection by regulating the expression of neurotrophic factors, exon regeneration, and anti-apoptosis. In addition, Rheb inhibits $A \beta$ formation through the induction of lysosomal and proteasomal degradation by binding to beta-secretase 1 (BACE) in Alzheimer's disease (AD) conditions.

In PD conditions, the role of mTOR remains controversial as it could exert either neuroprotective $[159,160]$ or neurotoxic $[161,162]$ effects in different PD models. Evidence accumulated in recent years has shown that mTOR signaling is altered during PD progression [163]. Various studies have demonstrated that 1-methyl-4-phenyl-1,2,3,6tetrahydropyridine (MPTP) and 6-hydroxydopamine (6-OHDA) suppress mTOR signaling and induce neuronal cell death [164-169]. Moreover, inhibition of mTORC1 by rapamycin can induce neuronal cell death in oxidative stress-induced condition [170], and regulated in DNA damage and development 1 (REDD1), an intrinsic repressor of mTORC1, was found to be highly expressed in a neurotoxin-induced cell model and in the substantia nigra of patients with PD [171]. Interestingly, one study showed that the activation of Akt/mTOR signaling in the dopaminergic neurons of the substantia nigra mediated axon protection in 
the neurotoxin lesions of a 6-OHDA-induced model [172], suggesting the importance of the Akt/Rheb/mTOR axis to protect axons during PD development. On the other hand, several studies have reported negative roles of mTOR, such as increasing the concentration of $\alpha$-synuclein in PD. Intracellular accumulation of $\alpha$-synuclein in structures known as Lewy bodies is a hallmark of PD and has been implicated in the pathogenesis of sporadic and familial PD [173-175]. It is known that clearance of $\alpha$-synuclein occurs through the process of autophagy, and mTOR acts as a negative regulator of this process [176]. In the $\alpha$-synuclein animal model, mTOR activity is increased, whereas the autophagy pathway is inactive [161,177]. These changes are associated with neurodegeneration in PD. The autophagy process occurs through the activation of an initiator called Unc51-like kinase 1 (ULK1) and the ATG complex [178]. mTOR inhibits the initiation of autophagy through the phosphorylation of the P757 site of ULK1. The reduction of autophagy by mTOR has been shown to be restored by rapamycin, an mTOR inhibitor, in an $\alpha$-synuclein animal model $[161,177]$. Given the importance of mTOR in the clearance of $\alpha$-synuclein, inhibition of mTOR signaling may be a viable therapeutic strategy. However, mTOR signaling regulates several essential cellular functions, including synaptic plasticity, memory formation, maintenance of nerve cells, and regulating NTF expression. Therefore, because mTOR is essential for cell survival and growth, maintaining an appropriate level of mTOR activity is vital.

Overall, the evidence reported to date suggests that Rheb-mTOR signaling is associated with neuronal loss that occurs in different neurodegenerative diseases and could therefore be a potential therapeutic target for a wide range of such disorders.

\section{Therapeutic Potential of Rheb(S16H) Transduction via AAV1 against Neurodegenerative Diseases}

As described earlier, the Rheb-mTOR signaling pathway is a key regulator of diverse mechanisms involved in the survival and regeneration of neurons. Accordingly, several studies have identified Rheb mutations that cause this protein to become constitutively active $[73,151]$. Our previous studies also demonstrated that the substitution of serine by histidine at position 16 of Rheb [Rheb(S16H)] significantly induced the expression of NTFs, such as GDNF, CNTF, and BDNF in the adult brain $[39,42,69,73,74,179,180]$. Our studies further showed that the upregulation of neuronal $\mathrm{Rheb}(\mathrm{S} 16 \mathrm{H})$ protects neurons from neuronal degeneration and promotes axonal regrowth in the hippocampus and the nigrostriatal dopamine system of the adult brain $[41,73,74,149,150,180]$. Our laboratory research further demonstrated that the activation of mTORC1 induced by Rheb(S16H) transduction in hippocampal neurons led to BDNF production, which protected the rat hippocampus against thrombin-induced neurotoxicity [40]. Similarly, Rheb(S16H) transduction using AAV1 viral vector in the hippocampus of transgenic 5XFAD mice, a transgenic mouse model of AD carrying five mutations associated with early-onset familial AD, was found to prevent against cognitive function impairment [39,42]. To date, the neuronal upregulation of Rheb(S16H) has demonstrated several neuroprotective effects in the hippocampus of the rat brain under neurotoxic conditions. Our previous studies have demonstrated that AAV1-Rheb(S16H) transduction in the hippocampal neurons prevents thrombin-induced neuronal cell death in the hippocampus of the rat brain [39,40]. More recently, AAV1$\mathrm{Rheb}(\mathrm{S} 16 \mathrm{H})$ transduction in our laboratory was found to have preventive effects against cognitive decline and LTP impairment in 5XFAD mice [42]. These beneficial effects could be mediated by the stimulation of neuronal BDNF production through the activation of the Rheb-mTORC1 signaling pathway after AAV1-Rheb(S16H) transduction, which can occur irrespective of the levels of neuroinflammatory molecules. Moreover, we recently found that Rheb(S16H) transduction using AAV1 viral vector in the hippocampal neurons increased the expression of GDNF in both neurons and astrocytes via autocrine and paracrine BDNF-TrkB signaling [39].

Similarly, in our other previous studies, we found that the expression of neuronal $\mathrm{Rheb}(\mathrm{S} 16 \mathrm{H})$ protects dopaminergic neurons through the upregulation of NTF expression in the substantia nigra in a neurotoxin-induced PD model. AAV1-hRheb(S16H) trans- 
duction of dopamine neurons protects against 6-OHDA-induced neurodegeneration and induces neuroprotective effect, including the abilities to both preserve and restore the dopaminergic axonal projections, through mTORC1 signaling $[149,150]$ Other studies have demonstrated that the transduction of dopaminergic neurons by AAV1-hRheb(S16H) induced the upregulation of both CNTF and CNTFR $\alpha$, which contributed to protection against 1-methyl-4-phenylpyridinium $\left(\mathrm{MPP}^{+}\right)$-induced neurotoxicity in nigrostriatal striatal dopaminergic projections [73]. In addition, Rheb(S16H) expression induced an increase in the levels of the phospho-cyclic adenosine monophosphate response element-binding protein ( $\mathrm{p}$-CREB) in dopaminergic neurons, which may be involved in the protective effects through the production of GDNF and BDNF [74]. Neurotoxic inflammation mediated by glial cells is considered as an important mechanism in the pathogenesis of PD and can exacerbate the cell loss of dopaminergic neurons and worsen the symptoms of the disease $[96,181]$. Our recent observations showed that Rheb(S16H) transduction in dopamine neurons played a role in the neuroprotection of the nigrostriatal dopamine system by inducing mTORC1 activation and BDNF/GDNF production without controlling neuroinflammation under $\mathrm{pKr}-2$ (endogenous microglia activator)-induced neurotoxic inflammatory environment [41] (Figure 2).

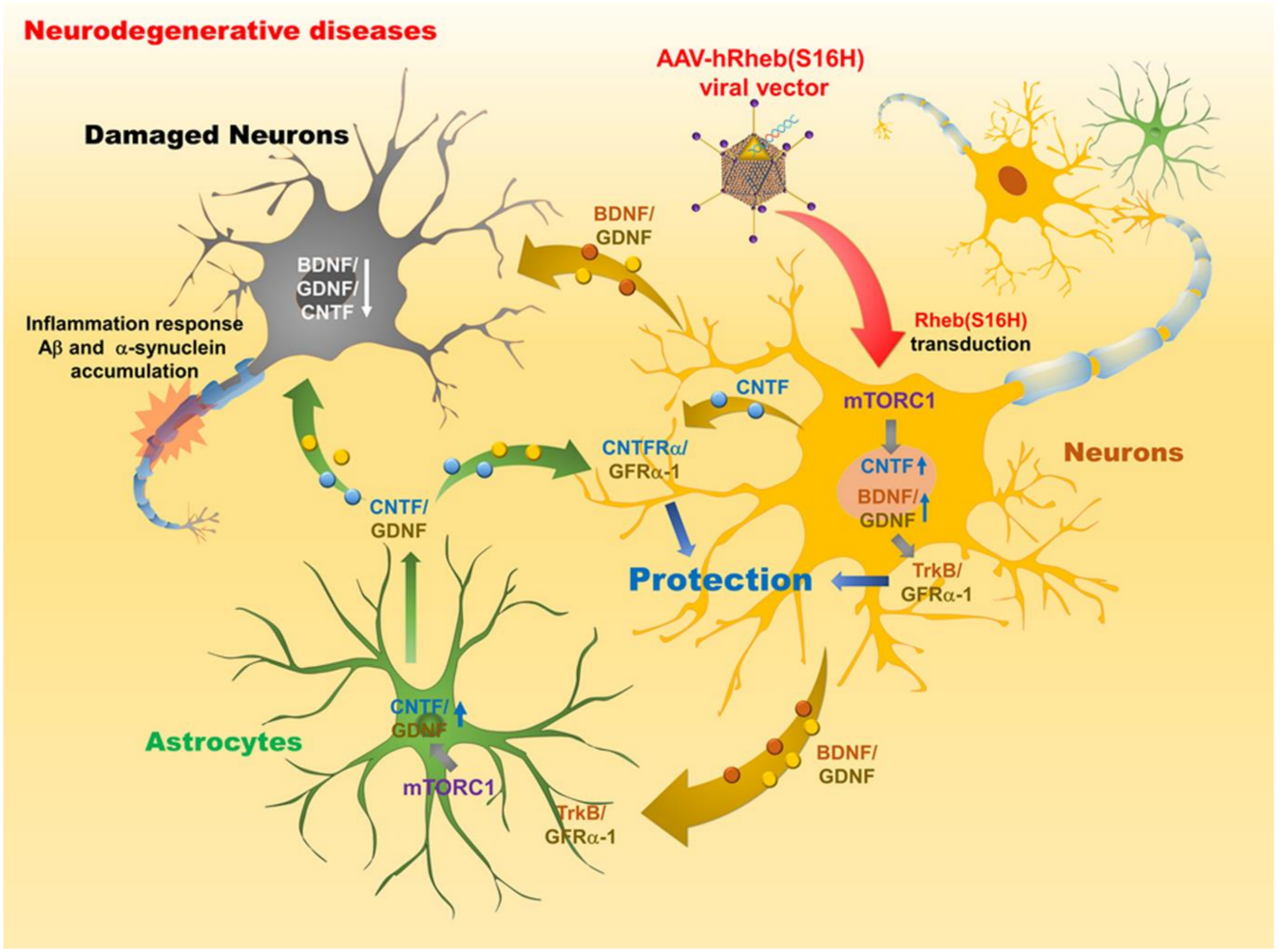

Figure 2. Schematic representation of the mechanisms of a neuroprotective system following AAV-hRheb(S16H) transduction in neurodegenerative diseases. In neurodegenerative diseases, various neurotoxicities, including A $\beta$ deposition, $\alpha$-synuclein aggregation, and inflammatory responses, induce axon loss and demyelination of specific neurons as well as reduction of neurotrophic factors (NTFs), leading to decreased memory/cognition and movement decline. hRheb(S16H) transduction of hippocampal or SNpc neurons using adeno-associated virus serotype 1 (AAV1) can induce the activation of mTORC1, which in turn stimulates the production of NTFs, such as brain-derived neurotrophic factor (BDNF), glial cell line-derived neurotrophic factor (GDNF), and ciliary neurotrophic factor (CNTF) in the neurons. Increased BDNF and GDNF expressions contribute to neuroprotection through the activation of TrkB/GFR $\alpha-1$ receptor, in the hippocampus and SNpc of brain, respectively. Moreover, CNTF production by hRheb(S16H) expression in SNpc neurons mediates neuroprotective effects through the CNTFR $\alpha$ receptor. In addition, BDNF/GDNF expression induced in hRheb(S16H)-expressing neurons result in functional interactions between neurons and astrocytes in the hippocampus, leading to the production of astrocytic CNTF and GDNF for hippocampal protection. 
In the hippocampus of the adult brain, AAV1-Rheb(S16H) transduction was found to induce a persistent increment in the expression levels of TrkB and CNTFR $\alpha$ within activated astrocytes and hippocampal neurons, respectively [39]. We also found that neuronal BDNF produced by AAV1-Rheb(S16H) transduction in hippocampal neurons induced the activation of astrocytes and mediated the production of CNTF through the activation of astrocytic TrkB. Therefore, the upregulation of neuronal BDNF and astrocytic CNTF by hRheb(S16H) transduction could have a positive synergistic effect on the survival of hippocampal neurons in vivo [39]. In our more recent analyses, AAV1-Rheb(S16H) transduction in 5XFAD mice was found to exert preventive effects against LTP impairment and cognitive decline [42]. These beneficial effects may be attributable to the interaction of multiple NTFs between neurons and astrocytes produced by the Rheb $(\mathrm{S} 16 \mathrm{H})$ transduction in hippocampal neurons, thereby resulting in neuroprotection in the hippocampus of 5XFAD mice (Figure 2).

\section{Conclusions}

Although a cure for neurodegenerative diseases has yet to be developed, there are several symptomatic treatments. Remarkably however, all these diseases will eventually progress. Our previous studies have clarified that the transduction of hippocampal neurons by Rheb $(\mathrm{S} 16 \mathrm{H})$ transduction stimulates NTF production, thereby strengthening the neuroprotective system and reducing neurodegeneration in the hippocampus and dopaminergic systems of the adult brain. Therefore, although further research is necessary to determine the clinical applicability of AAV1-Rheb $(\mathrm{S} 16 \mathrm{H})$ transduction to treat neurodegenerative diseases, this approach may be a useful strategy to protect neurons in the lesioned brain, and it may have beneficial effects in patients with neurological disorders, such as $\mathrm{AD}$ and PD.

Author Contributions: G.J.M. and S.R.K. designed and co-wrote the first manuscript. G.J.M. and Y.N. provided the references for the manuscript. Y.N. and S.R.K. edited the revised manuscript. S.R.K. supervised the entire manuscript. All authors contributed to the preparation of the manuscript and approved the final manuscript. All authors have read and agreed to the published version of the manuscript.

Funding: This work was supported by a grant from the National Research Foundation of Korea (NRF-2020R1A2C2007954).

Conflicts of Interest: The authors declare that there is no conflict of interest.

\section{References}

1. Dugger, B.N.; Dickson, D.W. Pathology of Neurodegenerative Diseases. Cold Spring Harb. Perspect. Biol. 2017, 9. [CrossRef]

2. Erkkinen, M.G.; Kim, M.O.; Geschwind, M.D. Clinical Neurology and Epidemiology of the Major Neurodegenerative Diseases. Cold Spring Harb. Perspect. Biol. 2018, 10. [CrossRef]

3. Fu, H.; Hardy, J.; Duff, K.E. Selective vulnerability in neurodegenerative diseases. Nat. Neurosci. 2018, 21, 1350-1358. [CrossRef] [PubMed]

4. Gitler, A.D.; Dhillon, P.; Shorter, J. Neurodegenerative disease: Models, mechanisms, and a new hope. Dis. Model Mech. 2017, 10, 499-502. [CrossRef] [PubMed]

5. Wyss-Coray, T. Ageing, neurodegeneration and brain rejuvenation. Nature 2016, 539, 180-186. [CrossRef] [PubMed]

6. Taylor, J.P.; Brown, R.H., Jr; Cleveland, D.W. Decoding ALS: From genes to mechanism. Nature 2016, 539, 197-206. [CrossRef]

7. Canter, R.G.; Penney, J.; Tsai, L.H. The road to restoring neural circuits for the treatment of Alzheimer's disease. Nature 2016, 539, 187-196. [CrossRef] [PubMed]

8. Thanan, R.; Oikawa, S.; Hiraku, Y.; Ohnishi, S.; Ma, N.; Pinlaor, S.; Yongvanit, P.; Kawanishi, S.; Murata, M. Oxidative stress and its significant roles in neurodegenerative diseases and cancer. Int. J. Mol. Sci. 2014, 16, 193-217. [CrossRef] [PubMed]

9. Dong, X.X.; Wang, Y.; Qin, Z.H. Molecular mechanisms of excitotoxicity and their relevance to pathogenesis of neurodegenerative diseases. Acta Pharmacol. Sin. 2009, 30, 379-387. [CrossRef]

10. Ridler, C. Neurodegenerative disease: Proteome points to synaptic dysfunction in dementia. Nat. Rev. Neurol. 2018, 14, 128. [CrossRef]

11. Gilhus, N.E.; Deuschl, G. Neuroinflammation-A common thread in neurological disorders. Nat. Rev. Neurol. 2019, 15, 429-430. [CrossRef] [PubMed] 
12. Ciechanover, A.; Kwon, Y.T. Degradation of misfolded proteins in neurodegenerative diseases: Therapeutic targets and strategies. Exp. Mol. Med. 2015, 47, e147. [CrossRef]

13. Hetz, C.; Saxena, S. ER stress and the unfolded protein response in neurodegeneration. Nat. Rev. Neurol. 2017, 13, 477-491. [CrossRef] [PubMed]

14. Norat, P.; Soldozy, S.; Sokolowski, J.D.; Gorick, C.M.; Kumar, J.S.; Chae, Y.; Yagmurlu, K.; Prada, F.; Walker, M.; Levitt, M.R.; et al. Mitochondrial dysfunction in neurological disorders: Exploring mitochondrial transplantation. NPJ Regen. Med. 2020, 5, 22. [CrossRef]

15. Yu, C.; Li, C.H.; Chen, S.; Yoo, H.; Qin, X.; Park, H. Decreased BDNF Release in Cortical Neurons of a Knock-in Mouse Model of Huntington's Disease. Sci. Rep. 2018, 8, 16976. [CrossRef] [PubMed]

16. Zuccato, C.; Marullo, M.; Vitali, B.; Tarditi, A.; Mariotti, C.; Valenza, M.; Lahiri, N.; Wild, E.J.; Sassone, J.; Ciammola, A.; et al. Brain-derived neurotrophic factor in patients with Huntington's disease. PLoS ONE 2011, 6, e22966. [CrossRef]

17. Hock, C.; Heese, K.; Hulette, C.; Rosenberg, C.; Otten, U. Region-specific neurotrophin imbalances in Alzheimer disease: Decreased levels of brain-derived neurotrophic factor and increased levels of nerve growth factor in hippocampus and cortical areas. Arch. Neurol. 2000, 57, 846-851. [CrossRef] [PubMed]

18. Ferrer, I.; Marin, C.; Rey, M.J.; Ribalta, T.; Goutan, E.; Blanco, R.; Tolosa, E.; Marti, E. BDNF and full-length and truncated TrkB expression in Alzheimer disease. Implications in therapeutic strategies. J. Neuropathol. Exp. Neurol. 1999, 58, 729-739. [CrossRef] [PubMed]

19. Peng, S.; Wuu, J.; Mufson, E.J.; Fahnestock, M. Precursor form of brain-derived neurotrophic factor and mature brainderived neurotrophic factor are decreased in the pre-clinical stages of Alzheimer's disease. J. Neurochem. 2005, 93, $1412-1421$. [CrossRef] [PubMed]

20. Chauhan, N.B.; Siegel, G.J.; Lee, J.M. Depletion of glial cell line-derived neurotrophic factor in substantia nigra neurons of Parkinson's disease brain. J. Chem. Neuroanat. 2001, 21, 277-288. [CrossRef]

21. Nagahara, A.H.; Merrill, D.A.; Coppola, G.; Tsukada, S.; Schroeder, B.E.; Shaked, G.M.; Wang, L.; Blesch, A.; Kim, A.; Conner, J.M.; et al. Neuroprotective effects of brain-derived neurotrophic factor in rodent and primate models of Alzheimer's disease. Nat. Med. 2009, 15, 331-337. [CrossRef] [PubMed]

22. Garcia, P.; Youssef, I.; Utvik, J.K.; Florent-Bechard, S.; Barthelemy, V.; Malaplate-Armand, C.; Kriem, B.; Stenger, C.; Koziel, V.; Olivier, J.L.; et al. Ciliary neurotrophic factor cell-based delivery prevents synaptic impairment and improves memory in mouse models of Alzheimer's disease. J. Neurosci. 2010, 30, 7516-7527. [CrossRef] [PubMed]

23. Yu, Y.; Li, S.; Xu, X.; Li, Y.; Guan, K.; Arnold, E.; Ding, J. Structural basis for the unique biological function of small GTPase RHEB. J. Biol. Chem. 2005, 280, 17093-17100. [CrossRef]

24. Aspuria, P.J.; Tamanoi, F. The Rheb family of GTP-binding proteins. Cell Signal. 2004, 16, 1105-1112. [CrossRef] [PubMed]

25. Saito, K.; Araki, Y.; Kontani, K.; Nishina, H.; Katada, T. Novel role of the small GTPase Rheb: Its implication in endocytic pathway independent of the activation of mammalian target of rapamycin. J. Biochem. 2005, 137, 423-430. [CrossRef]

26. Yamagata, K.; Sanders, L.K.; Kaufmann, W.E.; Yee, W.; Barnes, C.A.; Nathans, D.; Worley, P.F. rheb, a growth factor- and synaptic activity-regulated gene, encodes a novel Ras-related protein. J. Biol. Chem. 1994, 269, 16333-16339. [CrossRef]

27. Karassek, S.; Berghaus, C.; Schwarten, M.; Goemans, C.G.; Ohse, N.; Kock, G.; Jockers, K.; Neumann, S.; Gottfried, S.; Herrmann, C.; et al. Ras homolog enriched in brain (Rheb) enhances apoptotic signaling. J. Biol. Chem. 2010, 285, 33979-33991. [CrossRef]

28. Wu, D.; Klaw, M.C.; Connors, T.; Kholodilov, N.; Burke, R.E.; Tom, V.J. Expressing Constitutively Active Rheb in Adult Neurons after a Complete Spinal Cord Injury Enhances Axonal Regeneration beyond a Chondroitinase-Treated Glial Scar. J. Neurosci. 2015, 35, 11068-11080. [CrossRef]

29. Avruch, J.; Hara, K.; Lin, Y.; Liu, M.; Long, X.; Ortiz-Vega, S.; Yonezawa, K. Insulin and amino-acid regulation of mTOR signaling and kinase activity through the Rheb GTPase. Oncogene 2006, 25, 6361-6372. [CrossRef]

30. Patel, P.H.; Thapar, N.; Guo, L.; Martinez, M.; Maris, J.; Gau, C.L.; Lengyel, J.A.; Tamanoi, F. Drosophila Rheb GTPase is required for cell cycle progression and cell growth. J. Cell Sci. 2003, 116, 3601-3610. [CrossRef] [PubMed]

31. Sarkar, S.; Rubinsztein, D.C. Small molecule enhancers of autophagy for neurodegenerative diseases. Mol. Biosyst. 2008, 4, 895-901. [CrossRef]

32. Swiech, L.; Perycz, M.; Malik, A.; Jaworski, J. Role of mTOR in physiology and pathology of the nervous system. Biochim. Biophys. Acta 2008, 1784, 116-132. [CrossRef] [PubMed]

33. Rubinsztein, D.C. The roles of intracellular protein-degradation pathways in neurodegeneration. Nature 2006, 443, 780-786. [CrossRef] [PubMed]

34. Peng, C.; Trojanowski, J.Q.; Lee, V.M. Protein transmission in neurodegenerative disease. Nat. Rev. Neurol. 2020, 16, 199-212. [CrossRef] [PubMed]

35. Meade, R.M.; Fairlie, D.P.; Mason, J.M. Alpha-synuclein structure and Parkinson's disease—Lessons and emerging principles. Mol. Neurodegener. 2019, 14, 29. [CrossRef]

36. Sowa, A.S.; Martin, E.; Martins, I.M.; Schmidt, J.; Depping, R.; Weber, J.J.; Rother, F.; Hartmann, E.; Bader, M.; Riess, O.; et al. Karyopherin alpha-3 is a key protein in the pathogenesis of spinocerebellar ataxia type 3 controlling the nuclear localization of ataxin-3. Proc. Natl. Acad. Sci. USA 2018, 115, E2624-E2633. [CrossRef] [PubMed]

37. Lee, J.H.; Tecedor, L.; Chen, Y.H.; Monteys, A.M.; Sowada, M.J.; Thompson, L.M.; Davidson, B.L. Reinstating aberrant mTORC1 activity in Huntington's disease mice improves disease phenotypes. Neuron 2015, 85, 303-315. [CrossRef] [PubMed] 
38. Shahani, N.; Pryor, W.; Swarnkar, S.; Kholodilov, N.; Thinakaran, G.; Burke, R.E.; Subramaniam, S. Rheb GTPase regulates beta-secretase levels and amyloid beta generation. J. Biol. Chem. 2014, 289, 5799-5808. [CrossRef] [PubMed]

39. Jeon, M.T.; Moon, G.J.; Kim, S.; Choi, M.; Oh, Y.S.; Kim, D.W.; Kim, H.J.; Lee, K.J.; Choe, Y.; Ha, C.M.; et al. Neurotrophic interactions between neurons and astrocytes following AAV1-Rheb(S16H) transduction in the hippocampus in vivo. Br. J. Pharmacol. 2020, 177, 668-686. [CrossRef]

40. Jeon, M.T.; Nam, J.H.; Shin, W.H.; Leem, E.; Jeong, K.H.; Jung, U.J.; Bae, Y.S.; Jin, Y.H.; Kholodilov, N.; Burke, R.E.; et al. In vivo AAV1 transduction with hRheb(S16H) protects hippocampal neurons by BDNF production. Mol Ther. 2015, 23, 445-455. [CrossRef] [PubMed]

41. Kim, S.; Moon, G.J.; Oh, Y.S.; Park, J.; Shin, W.H.; Jeong, J.Y.; Choi, K.S.; Jin, B.K.; Kholodilov, N.; Burke, R.E.; et al. Protection of nigral dopaminergic neurons by AAV1 transduction with Rheb(S16H) against neurotoxic inflammation in vivo. Exp. Mol. Med. 2018, 50, e440. [CrossRef] [PubMed]

42. Moon, G.J.; Kim, S.; Jeon, M.T.; Lee, K.J.; Jang, I.S.; Nakamura, M.; Kim, S.R. Therapeutic Potential of AAV1-Rheb(S16H) Transduction Against Alzheimer's Disease. J. Clin. Med. 2019, 8, 2053. [CrossRef]

43. Chan-Palay, V. Alterations in the locus coeruleus in dementias of Alzheimer's and Parkinson's disease. Prog. Brain Res. 1991, 88, 625-630. [CrossRef]

44. Burke, W.J.; Park, D.H.; Chung, H.D.; Marshall, G.L.; Haring, J.H.; Joh, T.H. Evidence for decreased transport of tryptophan hydroxylase in Alzheimer's disease. Brain Res. 1990, 537, 83-87. [CrossRef]

45. Burke, W.J.; Chung, H.D.; Marshall, G.L.; Gillespie, K.N.; Joh, T.H. Evidence for decreased transport of PNMT protein in advanced Alzheimer's disease. J. Am. Geriatr. Soc. 1990, 38, 1275-1282. [CrossRef] [PubMed]

46. Tabaton, M.; Schenone, A.; Romagnoli, P.; Mancardi, G.L. A quantitative and ultrastructural study of substantia nigra and nucleus centralis superior in Alzheimer's disease. Acta Neuropathol. 1985, 68, 218-223. [CrossRef]

47. Whitehouse, P.J.; Price, D.L.; Struble, R.G.; Clark, A.W.; Coyle, J.T.; Delon, M.R. Alzheimer's disease and senile dementia: Loss of neurons in the basal forebrain. Science 1982, 215, 1237-1239. [CrossRef] [PubMed]

48. Cheshire, P.; Ayton, S.; Bertram, K.L.; Ling, H.; Li, A.; McLean, C.; Halliday, G.M.; O'Sullivan, S.S.; Revesz, T.; Finkelstein, D.I.; et al. Serotonergic markers in Parkinson's disease and levodopa-induced dyskinesias. Mov. Disord. 2015, 30, 796-804. [CrossRef]

49. Hall, H.; Reyes, S.; Landeck, N.; Bye, C.; Leanza, G.; Double, K.; Thompson, L.; Halliday, G.; Kirik, D. Hippocampal Lewy pathology and cholinergic dysfunction are associated with dementia in Parkinson's disease. Brain 2014, 137, 2493-2508. [CrossRef] [PubMed]

50. Damier, P.; Hirsch, E.C.; Agid, Y.; Graybiel, A.M. The substantia nigra of the human brain. II. Patterns of loss of dopaminecontaining neurons in Parkinson's disease. Brain 1999, 122, 1437-1448. [CrossRef]

51. Halliday, G.M.; Li, Y.W.; Blumbergs, P.C.; Joh, T.H.; Cotton, R.G.; Howe, P.R.; Blessing, W.W.; Geffen, L.B. Neuropathology of immunohistochemically identified brainstem neurons in Parkinson's disease. Ann. Neurol. 1990, 27, 373-385. [CrossRef]

52. Mann, D.M.; Yates, P.O. Pathological basis for neurotransmitter changes in Parkinson's disease. Neuropathol. Appl. Neurobiol. 1983, 9, 3-19. [CrossRef]

53. Deng, Y.P.; Reiner, A. Cholinergic interneurons in the Q140 knockin mouse model of Huntington's disease: Reductions in dendritic branching and thalamostriatal input. J. Comp. Neurol. 2016, 524, 3518-3529. [CrossRef]

54. Reinius, B.; Blunder, M.; Brett, F.M.; Eriksson, A.; Patra, K.; Jonsson, J.; Jazin, E.; Kullander, K. Conditional targeting of medium spiny neurons in the striatal matrix. Front. Behav. Neurosci. 2015, 9, 71. [CrossRef]

55. Rikani, A.A.; Choudhry, Z.; Choudhry, A.M.; Rizvi, N.; Ikram, H.; Mobassarah, N.J.; Tulli, S. The mechanism of degeneration of striatal neuronal subtypes in Huntington disease. Ann. Neurosci. 2014, 21, 112-114. [CrossRef]

56. Huot, P.; Levesque, M.; Parent, A. The fate of striatal dopaminergic neurons in Parkinson's disease and Huntington's chorea. Brain 2007, 130, 222-232. [CrossRef]

57. Behrens, P.F.; Franz, P.; Woodman, B.; Lindenberg, K.S.; Landwehrmeyer, G.B. Impaired glutamate transport and glutamateglutamine cycling: Downstream effects of the Huntington mutation. Brain 2002, 125, 1908-1922. [CrossRef]

58. Jimcy Platholi, F.S.L. Neurotrophic Factors. In Handbook of Developmental Neurotoxicology; Academic Press: Cambridge, MA, USA, 2018; pp. 55-64.

59. Huang, E.J.; Reichardt, L.F. Neurotrophins: Roles in neuronal development and function. Annu. Rev. Neurosci. 2001, 24, 677-736. [CrossRef] [PubMed]

60. Jiao, S.S.; Shen, L.L.; Zhu, C.; Bu, X.L.; Liu, Y.H.; Liu, C.H.; Yao, X.Q.; Zhang, L.L.; Zhou, H.D.; Walker, D.G.; et al. Brain-derived neurotrophic factor protects against tau-related neurodegeneration of Alzheimer's disease. Transl. Psychiatry 2016, 6, e907. [CrossRef] [PubMed]

61. Konishi, Y.; Yang, L.B.; He, P.; Lindholm, K.; Lu, B.; Li, R.; Shen, Y. Deficiency of GDNF Receptor GFRalpha1 in Alzheimer's Neurons Results in Neuronal Death. J. Neurosci. 2014, 34, 13127-13138. [CrossRef] [PubMed]

62. Kang, S.S.; Zhang, Z.; Liu, X.; Manfredsson, F.P.; Benskey, M.J.; Cao, X.; Xu, J.; Sun, Y.E.; Ye, K. TrkB neurotrophic activities are blocked by alpha-synuclein, triggering dopaminergic cell death in Parkinson's disease. Proc. Natl. Acad. Sci. USA 2017, 114, 10773-10778. [CrossRef] [PubMed]

63. Littrell, O.M.; Granholm, A.C.; Gerhardt, G.A.; Boger, H.A. Glial cell-line derived neurotrophic factor (GDNF) replacement attenuates motor impairments and nigrostriatal dopamine deficits in 12-month-old mice with a partial deletion of GDNF. Pharmacol. Biochem. Behav. 2013, 104, 10-19. [CrossRef] 
64. Howells, D.W.; Porritt, M.J.; Wong, J.Y.; Batchelor, P.E.; Kalnins, R.; Hughes, A.J.; Donnan, G.A. Reduced BDNF mRNA expression in the Parkinson's disease substantia nigra. Exp. Neurol. 2000, 166, 127-135. [CrossRef] [PubMed]

65. Canals, J.M.; Pineda, J.R.; Torres-Peraza, J.F.; Bosch, M.; Martin-Ibanez, R.; Munoz, M.T.; Mengod, G.; Ernfors, P.; Alberch, J. Brain-derived neurotrophic factor regulates the onset and severity of motor dysfunction associated with enkephalinergic neuronal degeneration in Huntington's disease. J. Neurosci. 2004, 24, 7727-7739. [CrossRef] [PubMed]

66. Zuccato, C.; Ciammola, A.; Rigamonti, D.; Leavitt, B.R.; Goffredo, D.; Conti, L.; MacDonald, M.E.; Friedlander, R.M.; Silani, V.; Hayden, M.R.; et al. Loss of huntingtin-mediated BDNF gene transcription in Huntington's disease. Science 2001, 293, 493-498. [CrossRef] [PubMed]

67. Schiaffino, L.; Bonafede, R.; Scambi, I.; Parrella, E.; Pizzi, M.; Mariotti, R. Acetylation state of RelA modulated by epigenetic drugs prolongs survival and induces a neuroprotective effect on ALS murine model. Sci. Rep. 2018, 8, 12875. [CrossRef] [PubMed]

68. Shruthi, S.; Sumitha, R.; Varghese, A.M.; Ashok, S.; Chandrasekhar Sagar, B.K.; Sathyaprabha, T.N.; Nalini, A.; Kramer, B.W.; Raju, T.R.; Vijayalakshmi, K.; et al. Brain-Derived Neurotrophic Factor Facilitates Functional Recovery from ALS-Cerebral Spinal Fluid-Induced Neurodegenerative Changes in the NSC-34 Motor Neuron Cell Line. Neurodegener. Dis. 2017, 17, 44-58. [CrossRef]

69. Yun, D.; Jeon, M.T.; Kim, H.J.; Moon, G.J.; Lee, S.; Ha, C.M.; Shin, M.; Kim, S.R. Induction of GDNF and GFRalpha-1 Following AAV1-Rheb(S16H) Administration in the Hippocampus in vivo. Exp. Neurobiol. 2020, 29, 164-175. [CrossRef]

70. Fan, C.H.; Ting, C.Y.; Lin, C.Y.; Chan, H.L.; Chang, Y.C.; Chen, Y.Y.; Liu, H.L.; Yeh, C.K. Noninvasive, Targeted, and Non-Viral Ultrasound-Mediated GDNF-Plasmid Delivery for Treatment of Parkinson's Disease. Sci. Rep. 2016, 6, 19579. [CrossRef]

71. Decressac, M.; Ulusoy, A.; Mattsson, B.; Georgievska, B.; Romero-Ramos, M.; Kirik, D.; Bjorklund, A. GDNF fails to exert neuroprotection in a rat alpha-synuclein model of Parkinson's disease. Brain 2011, 134, 2302-2311. [CrossRef] [PubMed]

72. Lo Bianco, C.; Deglon, N.; Pralong, W.; Aebischer, P. Lentiviral nigral delivery of GDNF does not prevent neurodegeneration in a genetic rat model of Parkinson's disease. Neurobiol. Dis. 2004, 17, 283-289. [CrossRef] [PubMed]

73. Jeong, K.H.; Nam, J.H.; Jin, B.K.; Kim, S.R. Activation of CNTF/CNTFRalpha signaling pathway by hRheb(S16H) transduction of dopaminergic neurons in vivo. PLoS ONE 2015, 10, e0121803. [CrossRef]

74. Nam, J.H.; Leem, E.; Jeon, M.T.; Jeong, K.H.; Park, J.W.; Jung, U.J.; Kholodilov, N.; Burke, R.E.; Jin, B.K.; Kim, S.R. Induction of GDNF and BDNF by hRheb(S16H) transduction of SNpc neurons: Neuroprotective mechanisms of hRheb(S16H) in a model of Parkinson's disease. Mol. Neurobiol. 2015, 51, 487-499. [CrossRef] [PubMed]

75. Brambilla, L.; Guidotti, G.; Martorana, F.; Iyer, A.M.; Aronica, E.; Valori, C.F.; Rossi, D. Disruption of the astrocytic TNFR1-GDNF axis accelerates motor neuron degeneration and disease progression in amyotrophic lateral sclerosis. Hum. Mol. Genet. 2016, 25, 3080-3095. [CrossRef]

76. Wang, L.J.; Lu, Y.Y.; Muramatsu, S.; Ikeguchi, K.; Fujimoto, K.; Okada, T.; Mizukami, H.; Matsushita, T.; Hanazono, Y.; Kume, A.; et al. Neuroprotective effects of glial cell line-derived neurotrophic factor mediated by an adeno-associated virus vector in a transgenic animal model of amyotrophic lateral sclerosis. J. Neurosci. 2002, 22, 6920-6928. [CrossRef] [PubMed]

77. Thomsen, G.M.; Alkaslasi, M.; Vit, J.P.; Lawless, G.; Godoy, M.; Gowing, G.; Shelest, O.; Svendsen, C.N. Systemic injection of AAV9-GDNF provides modest functional improvements in the SOD1(G93A) ALS rat but has adverse side effects. Gene Ther. 2017, 24, 245-252. [CrossRef]

78. Korkmaz, O.T.; Aytan, N.; Carreras, I.; Choi, J.K.; Kowall, N.W.; Jenkins, B.G.; Dedeoglu, A. 7,8-Dihydroxyflavone improves motor performance and enhances lower motor neuronal survival in a mouse model of amyotrophic lateral sclerosis. Neurosci. Lett. 2014, 566, 286-291. [CrossRef] [PubMed]

79. Querfurth, H.W.; LaFerla, F.M. Alzheimer's disease. N. Engl. J. Med. 2010, 362, 329-344. [CrossRef]

80. Cummings, J.L. Alzheimer's disease. N. Engl. J. Med. 2004, 351, 56-67. [CrossRef]

81. Kawas, C.H. Clinical practice. Early Alzheimer's disease. N. Engl. J. Med. 2003, 349, 1056-1063. [CrossRef]

82. Congdon, E.E.; Sigurdsson, E.M. Tau-targeting therapies for Alzheimer disease. Nat. Rev. Neurol. 2018, 14, 399-415. [CrossRef]

83. Oakley, H.; Cole, S.L.; Logan, S.; Maus, E.; Shao, P.; Craft, J.; Guillozet-Bongaarts, A.; Ohno, M.; Disterhoft, J.; Van Eldik, L.; et al. Intraneuronal beta-amyloid aggregates, neurodegeneration, and neuron loss in transgenic mice with five familial Alzheimer's disease mutations: Potential factors in amyloid plaque formation. J. Neurosci. 2006, 26, 10129-10140. [CrossRef] [PubMed]

84. Hampel, H.; Mesulam, M.M.; Cuello, A.C.; Farlow, M.R.; Giacobini, E.; Grossberg, G.T.; Khachaturian, A.S.; Vergallo, A.; Cavedo, E.; Snyder, P.J.; et al. The cholinergic system in the pathophysiology and treatment of Alzheimer's disease. Brain 2018, 141, 1917-1933. [CrossRef] [PubMed]

85. Schmitz, T.W.; Nathan Spreng, R.; The Alzheimer's Disease Neuroimaging Initiative. Basal forebrain degeneration precedes and predicts the cortical spread of Alzheimer's pathology. Nat. Commun. 2016, 7, 13249. [CrossRef] [PubMed]

86. Lee, J.; Fukumoto, H.; Orne, J.; Klucken, J.; Raju, S.; Vanderburg, C.R.; Irizarry, M.C.; Hyman, B.T.; Ingelsson, M. Decreased levels of BDNF protein in Alzheimer temporal cortex are independent of BDNF polymorphisms. Exp. Neurol. 2005, 194, 91-96. [CrossRef]

87. Wang, Z.H.; Xiang, J.; Liu, X.; Yu, S.P.; Manfredsson, F.P.; Sandoval, I.M.; Wu, S.; Wang, J.Z.; Ye, K. Deficiency in BDNF/TrkB Neurotrophic Activity Stimulates delta-Secretase by Upregulating C/EBPbeta in Alzheimer's Disease. Cell Rep. 2019, 28, 655-669.e5. [CrossRef] [PubMed]

88. Revilla, S.; Sunol, C.; Garcia-Mesa, Y.; Gimenez-Llort, L.; Sanfeliu, C.; Cristofol, R. Physical exercise improves synaptic dysfunction and recovers the loss of survival factors in 3xTg-AD mouse brain. Neuropharmacology 2014, 81, 55-63. [CrossRef] [PubMed] 
89. Straten, G.; Eschweiler, G.W.; Maetzler, W.; Laske, C.; Leyhe, T. Glial cell-line derived neurotrophic factor (GDNF) concentrations in cerebrospinal fluid and serum of patients with early Alzheimer's disease and normal controls. J. Alzheimers Dis. 2009, 18, 331-337. [CrossRef]

90. Li, W.; Wei, D.; Lin, J.; Liang, J.; Xie, X.; Song, K.; Huang, L. Dl-3-n-Butylphthalide Reduces Cognitive Impairment Induced by Chronic Cerebral Hypoperfusion Through GDNF/GFRalpha1/Ret Signaling Preventing Hippocampal Neuron Apoptosis. Front. Cell Neurosci. 2019, 13, 351. [CrossRef]

91. Scholz, D.; Chernyshova, Y.; Leist, M. Control of Abeta release from human neurons by differentiation status and RET signaling. Neurobiol. Aging 2013, 34, 184-199. [CrossRef] [PubMed]

92. Poewe, W.; Seppi, K.; Tanner, C.M.; Halliday, G.M.; Brundin, P.; Volkmann, J.; Schrag, A.E.; Lang, A.E. Parkinson disease. Nat. Rev. Dis. Primers 2017, 3, 17013. [CrossRef]

93. Tysnes, O.B.; Storstein, A. Epidemiology of Parkinson's disease. J. Neural Transm. 2017, 124, 901-905. [CrossRef] [PubMed]

94. Buddhala, C.; Loftin, S.K.; Kuley, B.M.; Cairns, N.J.; Campbell, M.C.; Perlmutter, J.S.; Kotzbauer, P.T. Dopaminergic, serotonergic, and noradrenergic deficits in Parkinson disease. Ann. Clin. Transl. Neurol. 2015, 2, 949-959. [CrossRef] [PubMed]

95. Muller, M.L.; Bohnen, N.I. Cholinergic dysfunction in Parkinson's disease. Curr. Neurol. Neurosci. Rep. 2013, $13,377$. [CrossRef] [PubMed]

96. Tan, E.K.; Chao, Y.X.; West, A.; Chan, L.L.; Poewe, W.; Jankovic, J. Parkinson disease and the immune system-Associations, mechanisms and therapeutics. Nat. Rev. Neurol. 2020, 16, 303-318. [CrossRef] [PubMed]

97. Sampaio, T.B.; Savall, A.S.; Gutierrez, M.E.Z.; Pinton, S. Neurotrophic factors in Alzheimer's and Parkinson's diseases: Implications for pathogenesis and therapy. Neural Regen. Res. 2017, 12, 549-557. [CrossRef] [PubMed]

98. Tome, D.; Fonseca, C.P.; Campos, F.L.; Baltazar, G. Role of Neurotrophic Factors in Parkinson's Disease. Curr. Pharm. Des. 2017, 23, 809-838. [CrossRef]

99. Jiang, L.; Zhang, H.; Wang, C.; Ming, F.; Shi, X.; Yang, M. Serum level of brain-derived neurotrophic factor in Parkinson's disease: A meta-analysis. Prog. Neuropsychopharmacol. Biol. Psychiatry 2019, 88, 168-174. [CrossRef] [PubMed]

100. Scalzo, P.; Kummer, A.; Bretas, T.L.; Cardoso, F.; Teixeira, A.L. Serum levels of brain-derived neurotrophic factor correlate with motor impairment in Parkinson's disease. J. Neurol. 2010, 257, 540-545. [CrossRef]

101. Rahmani, F.; Saghazadeh, A.; Rahmani, M.; Teixeira, A.L.; Rezaei, N.; Aghamollaii, V.; Ardebili, H.E. Plasma levels of brainderived neurotrophic factor in patients with Parkinson disease: A systematic review and meta-analysis. Brain Res. 2019, 1704, 127-136. [CrossRef]

102. Enterria-Morales, D.; Lopez-Lopez, I.; Lopez-Barneo, J.; d’Anglemont de Tassigny, X. Role of Glial Cell Line-Derived Neurotrophic Factor in the Maintenance of Adult Mesencephalic Catecholaminergic Neurons. Mov. Disord. 2020, 35, 565-576. [CrossRef]

103. Pascual, A.; Hidalgo-Figueroa, M.; Piruat, J.I.; Pintado, C.O.; Gomez-Diaz, R.; Lopez-Barneo, J. Absolute requirement of GDNF for adult catecholaminergic neuron survival. Nat. Neurosci. 2008, 11, 755-761. [CrossRef]

104. Grandoso, L.; Ponce, S.; Manuel, I.; Arrue, A.; Ruiz-Ortega, J.A.; Ulibarri, I.; Orive, G.; Hernandez, R.M.; Rodriguez, A.; RodriguezPuertas, R.; et al. Long-term survival of encapsulated GDNF secreting cells implanted within the striatum of parkinsonized rats. Int. J. Pharm. 2007, 343, 69-78. [CrossRef] [PubMed]

105. Kopra, J.; Vilenius, C.; Grealish, S.; Harma, M.A.; Varendi, K.; Lindholm, J.; Castren, E.; Voikar, V.; Bjorklund, A.; Piepponen, T.P.; et al. GDNF is not required for catecholaminergic neuron survival in vivo. Nat. Neurosci. 2015, 18, 319-322. [CrossRef] [PubMed]

106. Decressac, M.; Kadkhodaei, B.; Mattsson, B.; Laguna, A.; Perlmann, T.; Bjorklund, A. $\alpha$-Synuclein-induced down-regulation of Nurr1 disrupts GDNF signaling in nigral dopamine neurons. Sci. Transl. Med. 2012, 4, 163ra156. [CrossRef] [PubMed]

107. Su, X.; Fischer, D.L.; Li, X.; Bankiewicz, K.; Sortwell, C.E.; Federoff, H.J. Alpha-Synuclein mRNA Is Not Increased in Sporadic PD and Alpha-Synuclein Accumulation Does Not Block GDNF Signaling in Parkinson's Disease and Disease Models. Mol. Ther. 2017, 25, 2231-2235. [CrossRef]

108. Chmielarz, P.; Er, S.; Konovalova, J.; Bandres, L.; Hlushchuk, I.; Albert, K.; Panhelainen, A.; Luk, K.; Airavaara, M.; Domanskyi, A. GDNF/RET Signaling Pathway Activation Eliminates Lewy Body Pathology in Midbrain Dopamine Neurons. Mov. Disord. 2020, 35, 2279-2289. [CrossRef]

109. Nutt, J.G.; Burchiel, K.J.; Comella, C.L.; Jankovic, J.; Lang, A.E.; Laws, E.R., Jr.; Lozano, A.M.; Penn, R.D.; Simpson, R.K., Jr.; Stacy, M.; et al. Randomized, double-blind trial of glial cell line-derived neurotrophic factor (GDNF) in PD. Neurology 2003, 60, 69-73. [CrossRef]

110. Gill, S.S.; Patel, N.K.; Hotton, G.R.; O'Sullivan, K.; McCarter, R.; Bunnage, M.; Brooks, D.J.; Svendsen, C.N.; Heywood, P. Direct brain infusion of glial cell line-derived neurotrophic factor in Parkinson disease. Nat. Med. 2003, 9, 589-595. [CrossRef]

111. Love, S.; Plaha, P.; Patel, N.K.; Hotton, G.R.; Brooks, D.J.; Gill, S.S. Glial cell line-derived neurotrophic factor induces neuronal sprouting in human brain. Nat. Med. 2005, 11, 703-704. [CrossRef]

112. Slevin, J.T.; Gash, D.M.; Smith, C.D.; Gerhardt, G.A.; Kryscio, R.; Chebrolu, H.; Walton, A.; Wagner, R.; Young, A.B. Unilateral intraputamenal glial cell line-derived neurotrophic factor in patients with Parkinson disease: Response to 1 year of treatment and 1 year of withdrawal. J. Neurosurg. 2007, 106, 614-620. [CrossRef]

113. Slevin, J.T.; Gerhardt, G.A.; Smith, C.D.; Gash, D.M.; Kryscio, R.; Young, B. Improvement of bilateral motor functions in patients with Parkinson disease through the unilateral intraputaminal infusion of glial cell line-derived neurotrophic factor. J. Neurosurg. 2005, 102, 216-222. [CrossRef] 
114. Lang, A.E.; Gill, S.; Patel, N.K.; Lozano, A.; Nutt, J.G.; Penn, R.; Brooks, D.J.; Hotton, G.; Moro, E.; Heywood, P.; et al. Randomized controlled trial of intraputamenal glial cell line-derived neurotrophic factor infusion in Parkinson disease. Ann. Neurol. 2006, 59, 459-466. [CrossRef]

115. Patel, N.K.; Pavese, N.; Javed, S.; Hotton, G.R.; Brooks, D.J.; Gill, S.S. Benefits of putaminal GDNF infusion in Parkinson disease are maintained after GDNF cessation. Neurology 2013, 81, 1176-1178. [CrossRef] [PubMed]

116. Whone, A.L.; Boca, M.; Luz, M.; Woolley, M.; Mooney, L.; Dharia, S.; Broadfoot, J.; Cronin, D.; Schroers, C.; Barua, N.U.; et al. Extended Treatment with Glial Cell Line-Derived Neurotrophic Factor in Parkinson's Disease. J. Parkinsons Dis. 2019, 9, 301-313. [CrossRef] [PubMed]

117. Whone, A.; Luz, M.; Boca, M.; Woolley, M.; Mooney, L.; Dharia, S.; Broadfoot, J.; Cronin, D.; Schroers, C.; Barua, N.U.; et al. Randomized trial of intermittent intraputamenal glial cell line-derived neurotrophic factor in Parkinson's disease. Brain 2019, 142, 512-525. [CrossRef] [PubMed]

118. Turner, M.R.; Hardiman, O.; Benatar, M.; Brooks, B.R.; Chio, A.; de Carvalho, M.; Ince, P.G.; Lin, C.; Miller, R.G.; Mitsumoto, H.; et al. Controversies and priorities in amyotrophic lateral sclerosis. Lancet Neurol. 2013, 12, 310-322. [CrossRef]

119. Cleveland, D.W.; Rothstein, J.D. From Charcot to Lou Gehrig: Deciphering selective motor neuron death in ALS. Nat. Rev. Neurosci. 2001, 2, 806-819. [CrossRef]

120. Koliatsos, V.E.; Clatterbuck, R.E.; Winslow, J.W.; Cayouette, M.H.; Price, D.L. Evidence that brain-derived neurotrophic factor is a trophic factor for motor neurons in vivo. Neuron 1993, 10, 359-367. [CrossRef]

121. Oppenheim, R.W.; Yin, Q.W.; Prevette, D.; Yan, Q. Brain-derived neurotrophic factor rescues developing avian motoneurons from cell death. Nature 1992, 360, 755-757. [CrossRef] [PubMed]

122. Almeida, R.D.; Manadas, B.J.; Melo, C.V.; Gomes, J.R.; Mendes, C.S.; Graos, M.M.; Carvalho, R.F.; Carvalho, A.P.; Duarte, C.B. Neuroprotection by BDNF against glutamate-induced apoptotic cell death is mediated by ERK and PI3-kinase pathways. Cell Death Differ. 2005, 12, 1329-1343. [CrossRef]

123. Guerzoni, L.P.; Nicolas, V.; Angelova, A. In Vitro Modulation of TrkB Receptor Signaling upon Sequential Delivery of CurcuminDHA Loaded Carriers Towards Promoting Neuronal Survival. Pharm. Res. 2017, 34, 492-505. [CrossRef]

124. Mojsilovic-Petrovic, J.; Jeong, G.B.; Crocker, A.; Arneja, A.; David, S.; Russell, D.S.; Kalb, R.G. Protecting motor neurons from toxic insult by antagonism of adenosine A2a and Trk receptors. J. Neurosci. 2006, 26, 9250-9263. [CrossRef]

125. Hu, P.; Kalb, R.G. BDNF heightens the sensitivity of motor neurons to excitotoxic insults through activation of TrkB. J. Neurochem. 2003, 84, 1421-1430. [CrossRef]

126. Kafitz, K.W.; Rose, C.R.; Thoenen, H.; Konnerth, A. Neurotrophin-evoked rapid excitation through TrkB receptors. Nature 1999, 401, 918-921. [CrossRef] [PubMed]

127. Mojsilovic-Petrovic, J.; Arneja, A.; Kalb, R.G. Enprofylline protects motor neurons from in vitro excitotoxic challenge. Neurodegener. Dis. 2005, 2, 160-165. [CrossRef] [PubMed]

128. Fryer, H.J.; Wolf, D.H.; Knox, R.J.; Strittmatter, S.M.; Pennica, D.; O’Leary, R.M.; Russell, D.S.; Kalb, R.G. Brain-derived neurotrophic factor induces excitotoxic sensitivity in cultured embryonic rat spinal motor neurons through activation of the phosphatidylinositol 3-kinase pathway. J. Neurochem. 2000, 74, 582-595. [CrossRef]

129. Kust, B.M.; Copray, J.C.; Brouwer, N.; Troost, D.; Boddeke, H.W. Elevated levels of neurotrophins in human biceps brachii tissue of amyotrophic lateral sclerosis. Exp. Neurol. 2002, 177, 419-427. [CrossRef]

130. Grundstrom, E.; Lindholm, D.; Johansson, A.; Blennow, K.; Askmark, H. GDNF but not BDNF is increased in cerebrospinal fluid in amyotrophic lateral sclerosis. Neuroreport 2000, 11, 1781-1783. [CrossRef] [PubMed]

131. Saba, J.; Lopez Couselo, F.; Turati, J.; Carniglia, L.; Durand, D.; de Laurentiis, A.; Lasaga, M.; Caruso, C. Astrocytes from cortex and striatum show differential responses to mitochondrial toxin and BDNF: Implications for protection of striatal neurons expressing mutant huntingtin. J. Neuroinflamm. 2020, 17, 290. [CrossRef]

132. Kowianski, P.; Lietzau, G.; Czuba, E.; Waskow, M.; Steliga, A.; Morys, J. BDNF: A Key Factor with Multipotent Impact on Brain Signaling and Synaptic Plasticity. Cell Mol. Neurobiol. 2018, 38, 579-593. [CrossRef]

133. Causing, C.G.; Gloster, A.; Aloyz, R.; Bamji, S.X.; Chang, E.; Fawcett, J.; Kuchel, G.; Miller, F.D. Synaptic innervation density is regulated by neuron-derived BDNF. Neuron 1997, 18, 257-267. [CrossRef]

134. Talbott, J.F.; Cao, Q.; Bertram, J.; Nkansah, M.; Benton, R.L.; Lavik, E.; Whittemore, S.R. CNTF promotes the survival and differentiation of adult spinal cord-derived oligodendrocyte precursor cells in vitro but fails to promote remyelination in vivo. Exp. Neurol. 2007, 204, 485-489. [CrossRef] [PubMed]

135. Duarte Azevedo, M.; Sander, S.; Tenenbaum, L. GDNF, A Neuron-Derived Factor Upregulated in Glial Cells during Disease. J. Clin. Med. 2020, 9, 456. [CrossRef] [PubMed]

136. Nakagawa, T.; Schwartz, J.P. Gene expression profiles of reactive astrocytes in dopamine-depleted striatum. Brain Pathol. 2004, 14, 275-280. [CrossRef] [PubMed]

137. Chang, Y.P.; Fang, K.M.; Lee, T.I.; Tzeng, S.F. Regulation of microglial activities by glial cell line derived neurotrophic factor. J. Cell Biochem. 2006, 97, 501-511. [CrossRef] [PubMed]

138. Longo, F.M.; Yang, T.; Knowles, J.K.; Xie, Y.; Moore, L.A.; Massa, S.M. Small molecule neurotrophin receptor ligands: Novel strategies for targeting Alzheimer's disease mechanisms. Curr. Alzheimer Res. 2007, 4, 503-506. [CrossRef] [PubMed]

139. Poduslo, J.F.; Curran, G.L. Permeability at the blood-brain and blood-nerve barriers of the neurotrophic factors: NGF, CNTF, NT-3, BDNF. Brain Res. Mol. Brain Res. 1996, 36, 280-286. [CrossRef] 
140. Abramson, J.H. The four basic types of evaluation: Clinical reviews, clinical trials, program reviews, and program trials. Public Health Rep. 1979, 94, 210-215. [PubMed]

141. Thoenen, H.; Sendtner, M. Neurotrophins: From enthusiastic expectations through sobering experiences to rational therapeutic approaches. Nat. Neurosci. 2002, 5, 1046-1050. [CrossRef] [PubMed]

142. Henriques, A.; Pitzer, C.; Schneider, A. Neurotrophic growth factors for the treatment of amyotrophic lateral sclerosis: Where do we stand? Front. Neurosci. 2010, 4, 32. [CrossRef] [PubMed]

143. Jiang, G.; Wang, W.; Cao, Q.; Gu, J.; Mi, X.; Wang, K.; Chen, G.; Wang, X. Insulin growth factor-1 (IGF-1) enhances hippocampal excitatory and seizure activity through IGF-1 receptor-mediated mechanisms in the epileptic brain. Clin. Sci. 2015, 129, 1047-1060. [CrossRef]

144. Binder, D.K.; Croll, S.D.; Gall, C.M.; Scharfman, H.E. BDNF and epilepsy: Too much of a good thing? Trends Neurosci. 2001, 24, 47-53. [CrossRef]

145. Dibble, C.C.; Elis, W.; Menon, S.; Qin, W.; Klekota, J.; Asara, J.M.; Finan, P.M.; Kwiatkowski, D.J.; Murphy, L.O.; Manning, B.D. TBC1D7 is a third subunit of the TSC1-TSC2 complex upstream of mTORC1. Mol. Cell 2012, 47, 535-546. [CrossRef]

146. Dibble, C.C.; Cantley, L.C. Regulation of mTORC1 by PI3K signaling. Trends Cell Biol. 2015, 25, 545-555. [CrossRef] [PubMed]

147. Gupta, A.; Dey, C.S. PTEN, a widely known negative regulator of insulin/PI3K signaling, positively regulates neuronal insulin resistance. Mol. Biol. Cell 2012, 23, 3882-3898. [CrossRef] [PubMed]

148. Zoncu, R.; Efeyan, A.; Sabatini, D.M. mTOR: From growth signal integration to cancer, diabetes and ageing. Nat. Rev. Mol. Cell Biol 2011, 12, 21-35. [CrossRef]

149. Kim, S.R.; Kareva, T.; Yarygina, O.; Kholodilov, N.; Burke, R.E. AAV transduction of dopamine neurons with constitutively active Rheb protects from neurodegeneration and mediates axon regrowth. Mol. Ther. 2012, 20, 275-286. [CrossRef]

150. Kim, S.R.; Chen, X.; Oo, T.F.; Kareva, T.; Yarygina, O.; Wang, C.; During, M.; Kholodilov, N.; Burke, R.E. Dopaminergic pathway reconstruction by Akt/Rheb-induced axon regeneration. Ann. Neurol. 2011, 70, 110-120. [CrossRef] [PubMed]

151. Moon, G.J.; Shin, M.; Kim, S.R. Upregulation of Neuronal Rheb(S16H) for Hippocampal Protection in the Adult Brain. Int. J. Mol. Sci. 2020, 21, 2023. [CrossRef] [PubMed]

152. Park, K.K.; Liu, K.; Hu, Y.; Smith, P.D.; Wang, C.; Cai, B.; Xu, B.; Connolly, L.; Kramvis, I.; Sahin, M.; et al. Promoting axon regeneration in the adult CNS by modulation of the PTEN/mTOR pathway. Science 2008, 322, 963-966. [CrossRef]

153. Li, Y.H.; Werner, H.; Puschel, A.W. Rheb and mTOR regulate neuronal polarity through Rap1B. J. Biol. Chem. 2008, 283, 33784-33792. [CrossRef]

154. Tavazoie, S.F.; Alvarez, V.A.; Ridenour, D.A.; Kwiatkowski, D.J.; Sabatini, B.L. Regulation of neuronal morphology and function by the tumor suppressors Tsc1 and Tsc2. Nat. Neurosci. 2005, 8, 1727-1734. [CrossRef]

155. Choi, Y.J.; Di Nardo, A.; Kramvis, I.; Meikle, L.; Kwiatkowski, D.J.; Sahin, M.; He, X. Tuberous sclerosis complex proteins control axon formation. Genes Dev. 2008, 22, 2485-2495. [CrossRef]

156. Jaworski, J.; Sheng, M. The growing role of mTOR in neuronal development and plasticity. Mol. Neurobiol. 2006, 34, 205-219. [CrossRef]

157. Banerjee, R.; Beal, M.F.; Thomas, B. Autophagy in neurodegenerative disorders: Pathogenic roles and therapeutic implications. Trends Neurosci. 2010, 33, 541-549. [CrossRef] [PubMed]

158. Shahani, N.; Huang, W.C.; Varnum, M.; Page, D.T.; Subramaniam, S. Forebrain depletion of Rheb GTPase elicits spatial memory deficits in mice. Neurobiol. Aging 2017, 50, 134-143. [CrossRef]

159. Domanskyi, A.; Geissler, C.; Vinnikov, I.A.; Alter, H.; Schober, A.; Vogt, M.A.; Gass, P.; Parlato, R.; Schutz, G. Pten ablation in adult dopaminergic neurons is neuroprotective in Parkinson's disease models. FASEB J. 2011, 25, 2898-2910. [CrossRef] [PubMed]

160. Malagelada, C.; Jin, Z.H.; Greene, L.A. RTP801 is induced in Parkinson's disease and mediates neuron death by inhibiting Akt phosphorylation/activation. J. Neurosci. 2008, 28, 14363-14371. [CrossRef]

161. Crews, L.; Spencer, B.; Desplats, P.; Patrick, C.; Paulino, A.; Rockenstein, E.; Hansen, L.; Adame, A.; Galasko, D.; Masliah, E. Selective molecular alterations in the autophagy pathway in patients with Lewy body disease and in models of alphasynucleinopathy. PLoS ONE 2010, 5, e9313. [CrossRef]

162. Pan, T.; Rawal, P.; Wu, Y.; Xie, W.; Jankovic, J.; Le, W. Rapamycin protects against rotenone-induced apoptosis through autophagy induction. Neuroscience 2009, 164, 541-551. [CrossRef] [PubMed]

163. Bockaert, J.; Marin, P. mTOR in Brain Physiology and Pathologies. Physiol. Rev. 2015, 95, 1157-1187. [CrossRef] [PubMed]

164. Zhou, Q.; Liu, C.; Liu, W.; Zhang, H.; Zhang, R.; Liu, J.; Zhang, J.; Xu, C.; Liu, L.; Huang, S.; et al. Rotenone induction of hydrogen peroxide inhibits mTOR-mediated S6K1 and 4E-BP1/eIF4E pathways, leading to neuronal apoptosis. Toxicol. Sci. 2015, 143, 81-96. [CrossRef] [PubMed]

165. Xu, Y.; Liu, C.; Chen, S.; Ye, Y.; Guo, M.; Ren, Q.; Liu, L.; Zhang, H.; Xu, C.; Zhou, Q.; et al. Activation of AMPK and inactivation of Akt result in suppression of mTOR-mediated S6K1 and 4E-BP1 pathways leading to neuronal cell death in in vitro models of Parkinson's disease. Cell Signal. 2014, 26, 1680-1689. [CrossRef]

166. Rodriguez-Blanco, J.; Martin, V.; Garcia-Santos, G.; Herrera, F.; Casado-Zapico, S.; Antolin, I.; Rodriguez, C. Cooperative action of JNK and AKT/mTOR in 1-methyl-4-phenylpyridinium-induced autophagy of neuronal PC12 cells. J. Neurosci. Res. 2012, 90, 1850-1860. [CrossRef] [PubMed]

167. Selvaraj, S.; Sun, Y.; Watt, J.A.; Wang, S.; Lei, S.; Birnbaumer, L.; Singh, B.B. Neurotoxin-induced ER stress in mouse dopaminergic neurons involves downregulation of TRPC1 and inhibition of AKT/mTOR signaling. J. Clin. Invest. 2012, 122, 1354-1367. [CrossRef] [PubMed] 
168. Rieker, C.; Engblom, D.; Kreiner, G.; Domanskyi, A.; Schober, A.; Stotz, S.; Neumann, M.; Yuan, X.; Grummt, I.; Schutz, G.; et al. Nucleolar disruption in dopaminergic neurons leads to oxidative damage and parkinsonism through repression of mammalian target of rapamycin signaling. J. Neurosci. 2011, 31, 453-460. [CrossRef]

169. Chen, L.; Xu, B.; Liu, L.; Luo, Y.; Yin, J.; Zhou, H.; Chen, W.; Shen, T.; Han, X.; Huang, S. Hydrogen peroxide inhibits mTOR signaling by activation of AMPKalpha leading to apoptosis of neuronal cells. Lab. Invest. 2010, 90, 762-773. [CrossRef] [PubMed]

170. Choi, K.C.; Kim, S.H.; Ha, J.Y.; Kim, S.T.; Son, J.H. A novel mTOR activating protein protects dopamine neurons against oxidative stress by repressing autophagy related cell death. J. Neurochem. 2010, 112, 366-376. [CrossRef]

171. Malagelada, C.; Ryu, E.J.; Biswas, S.C.; Jackson-Lewis, V.; Greene, L.A. RTP801 is elevated in Parkinson brain substantia nigral neurons and mediates death in cellular models of Parkinson's disease by a mechanism involving mammalian target of rapamycin inactivation. J. Neurosci. 2006, 26, 9996-10005. [CrossRef]

172. Cheng, H.C.; Kim, S.R.; Oo, T.F.; Kareva, T.; Yarygina, O.; Rzhetskaya, M.; Wang, C.; During, M.; Talloczy, Z.; Tanaka, K.; et al. Akt suppresses retrograde degeneration of dopaminergic axons by inhibition of macroautophagy. J. Neurosci. 2011, 31, $2125-2135$. [CrossRef] [PubMed]

173. Wong, Y.C.; Krainc, D. alpha-synuclein toxicity in neurodegeneration: Mechanism and therapeutic strategies. Nat. Med. 2017, 23, 1-13. [CrossRef] [PubMed]

174. Recasens, A.; Dehay, B.; Bove, J.; Carballo-Carbajal, I.; Dovero, S.; Perez-Villalba, A.; Fernagut, P.O.; Blesa, J.; Parent, A.; Perier, C.; et al. Lewy body extracts from Parkinson disease brains trigger alpha-synuclein pathology and neurodegeneration in mice and monkeys. Ann. Neurol. 2014, 75, 351-362. [CrossRef] [PubMed]

175. Lee, V.M.; Trojanowski, J.Q. Mechanisms of Parkinson's disease linked to pathological alpha-synuclein: New targets for drug discovery. Neuron 2006, 52, 33-38. [CrossRef]

176. Ramalingam, M.; Huh, Y.J.; Lee, Y.I. The Impairments of alpha-Synuclein and Mechanistic Target of Rapamycin in RotenoneInduced SH-SY5Y Cells and Mice Model of Parkinson's Disease. Front. Neurosci. 2019, 13, 1028. [CrossRef] [PubMed]

177. Gao, S.; Duan, C.; Gao, G.; Wang, X.; Yang, H. Alpha-synuclein overexpression negatively regulates insulin receptor substrate 1 by activating mTORC1/S6K1 signaling. Int. J. Biochem. Cell Biol. 2015, 64, 25-33. [CrossRef]

178. Kim, J.; Kundu, M.; Viollet, B.; Guan, K.L. AMPK and mTOR regulate autophagy through direct phosphorylation of Ulk1. Nat. Cell Biol. 2011, 13, 132-141. [CrossRef]

179. Yoon, D.; Jeon, M.T.; Woon Kim, D.; Kim, S.R. Treatment with AAV1-Rheb(S16H) provides neuroprotection in a mouse model of photothrombosis-induced ischemic stroke. Neuroreport 2020, 31, 971-978. [CrossRef]

180. Jeon, M.T.; Kim, S.R. Roles of Rheb(S16H) in substantia nigra pars compacta dopaminergic neurons in vivo. Biomed. Rep. 2015, 3, 137-140. [CrossRef]

181. Wang, Q.; Liu, Y.; Zhou, J. Neuroinflammation in Parkinson's disease and its potential as therapeutic target. Transl. Neurodegener. 2015, 4, 19. [CrossRef] [PubMed] 